\title{
Composition, distribution and biomass of benthic macrophyte communities from lake Baciver, a spanish alpine lake in the central Pyrenees
}

\author{
E. Ballesteros ${ }^{1}$ \\ E. Gacia2 \\ L. Camarero ${ }^{2}$
}

Keywords : macrophytes, specific composition, biomass, alpine lake, Pyrenees.

Species composition, distribution and biomass of benthic macrophyte communities have been studied in a high mountain, oligotrophic, softwater lake from the Central Pyrenees. Isoetids (Isoetes lacust ris L., Isoetes setacea Lam., Subularia aquarica L. and Eleocharis acicularis (L.) Roemer \& Schultes) are the dominant macrophytes in areas over 2-3 meters in depth. Natopotamids (Sparganium angustifolium Michx.) are restricted to shallow waters. Algae (Nitella gracilis (Smith) Agardh) only predominate in deep waters. Three main communities have been distinguished : the Sparganium angzistifo-

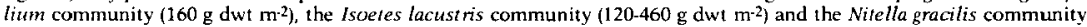

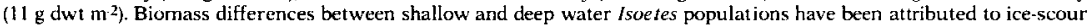
stress. Neither irradiance nor slope can explain the lower boundaries observed in the distribution of vascular plants ; sediment features may be responsible for them. Mean lake macrophyte biomass amounts to $140 \mathrm{~g} \mathrm{dwt} \mathrm{m-2(20} \mathrm{g} \mathrm{C} \mathrm{m-2),}$ a very high value if compared with boreal lakes with similar limnological characteristics.

Composition, distribution et hiomasse des communautés de macrophytes henthiques d'un lac alpin des Pyrénées centrales : le lac Baciver (Espagne).

Mots clés : macrophytes, composition specifique, biomasse, lac alpin, Pyrénées.

La composition spécifique, la distribution et la biomasse des communautés benthiques d'un lac de haute montagne des Pyrénées centrales sont étudiées. Les Isoetides (Isoetes lacustris L., Isoetes setacea Lam., Stibularia aquatica L. et Eleocharis acicularis (L.) Roemer \& Schultes représentent la végétation dominante au-dessus des $2.3 \mathrm{~m}$ de profondeur. Les Natopotamides (Sparganihtm angtisitolitum Michx.) sont restreints aux eaux peu profondes. Les Algues (Nitella gracilis (Smith) Agardh) predominent seulement dans les eaux profondes.

Trois communautés ont été distinguées : celle à Sparganium angustifolium, celle à lsoetes lacusiris et celle à Nitella gracilis. Les différences de biomasse constatées parmi les peuplements superficiels et profonds d'Isoetes lacustris sont attribuées au stress occasionné par la pression et le mouvement de la glace pendant l'hiver. Les limites bathymétriques inférieures des peuplements de plantes vasculaires ne peuvent pas être attribuées à une irradiation insuffisante ou à une pente excessive : quelques caractéristiques non déterminées du sédiment ou le mode de sédimentation peuvent en être responsables. La biomasse macrophytique moyenne du lac atteint $140 \mathrm{~g} \mathrm{ps} \mathrm{m}^{-2}$ : comparée à celle d'autres lacs de la région boréale à caractéristiques limnologiques semblables, elle est considérable.

\section{Introduction}

Phyt obenthic communities from high mountain lakes in the Pyrenees have been scarcely studied with the exception of the studies made in the lake

1. Centre d'Estudis Avançats de Blanes - CSIC. 17300 Blanes, Girona, Spain.

2. Departement d'Ecologia. Facultat de Biologia. Diagonal 645. 08028 Barcelona. Spain. of Port Bielh (Capblancq 1973, Capblancq \& Laville 1983). The only references to the phytobenthos of these high mountain lakes refer to floristic data (see, for example, Coste \& Soulié 1912, Campàs 1979, Carrillo 1984, Ballesteros 1988) sometimes supported by measures of physical and chemical parameters of the water (Margalef Mir 1981, Ballesteros \& Gacia 1988). Phytosociological studies have been made in some lakes (Braun Blanquel 1948, Carrillo 
1984), but there are no quantitative data about these submerged communities.

A detailed study of the vegetation of a typical lake is fully justified because of the patchy distribution of the species caused by changes in underwater irradiance, hydrodynamism and sediment characteristics. The knowledge of phytobenthic biomass and production is also very interesting because it can be used to determine daily and seasonal dynamics of some parameters in the lake as a result of changes in photosynthesis and respiration. Previous to the evaluation of dynamics, it is necessary to make an exhaustive description of the submerged vegetation of a typical alpine lake.

\section{Study area}

Lake Baciver is located in the Spanish Central Pyrenees, Val d'Aran, (UTM 31 T CH348294), at 2120 meters above sea level. Its origin is related to glacial overdeepening and subsequent morainic obstruction. Intrusive rocks (biotite-granodiorite and quartz-diorite) from the Carboniferous constitute the basin. The lake is placed over glaciofluvial and alluvial materials from the post-glacial Quaternary. Characteristic subalpine and alpine plant associations, typical of the granitic massifs of the Central Pyrenees constitute the vegetation of the basin. The area is dominated by the acidophilous shrub. Rhododendron ferrugineum L. with Pinus uncinata Miller ex Mirbel (Rhododendro-Pinetum uncinatea) and alpine acidophilous meadows of Festuca eskia Ramond ex DC (Festucion eskiae) and Carex curvula All (Festucion airoidus). Lake Baciver has many features in common with some other oligotrophic pyrenean lakes : small size, extensive shallow areas and clear soft waters (Table 1). Ice cover begins in November with the maximum snow cover in April. Thaw does not occur until late May, so the lake remains frozen for almost seven months.

Table I. Limnological features of Lake Baciver water (ranges).

$\begin{array}{lc}\text { Conductivity }\left(\mu \mathrm{S} \mathrm{cm}^{-1}\right) & 11.7-17.0 \\ \text { pH } & 6.30-7.15 \\ \text { Alkalinity (meq 1-1) } & 0.01-0.14 \\ \left.\text { Ammonium ( } \mu \mathrm{mols} \mathrm{1}^{-1}\right) & 0.02-3.71 \\ \text { Nitrites }(\mu \text { mols 1-1) } & 0.01-0.03 \\ \text { Nitrates }(\mu \text { mols 1-1) } & 5-10 \\ \text { Phosphates ( } \mu \text { mols 1-1) } & 0.03-0.08 \\ \left.\text { Particulate Phosphorus ( } \mu \text { gr-at } 1^{-1}\right) & 0.12-0.25\end{array}$

\section{Materials and Methods}

Lake morphometry has been elaborated from a series of bathymetric transects made with an echo-sounder. The transects were spaced at 20 meters intervals. The perimeter of the lake was obtained from an enlargement of an aerial photograph, at a scale 1 ; 1800. Cartography of underwater vegetation was made using SCLBA, by the examination of the same transects used for bathymetry. Vegetation units were distinguished in terms of dominant species.

Periodical visits (at least once a month) have been made to the lake in order to describe vegetation and its changes through the year. Samples of each vegetation unit have been collected using SCUBA (Boudouresque 1971) at the time when plants were assumed to have reached their maximum biomass (July for Isoetes lacess ris and August for Sparganium angustifolium). An area of $400 \mathrm{~cm}^{2}$ was delimitated, cut and extracted from the bottom. Depth of the sediment collected always exceeded $15 \mathrm{~cm}$, so underground biomass was also removed. The resultant block of macrophytes and sediment was carried up to the surface, cleaned of sediment and detritus in situ, fixed in $4 \%$ formaldehyde and sorted in the laboratory. Plants were dried at $105^{\circ} \mathrm{C}$ until constant weight (24 hours) (Sand Jensen \& Sondergaard 1979). Conversion to grams of carbon was performed from determinations of carbon content with a Carlo-Erba Nitrogen Analyzer 1500.

The Isoetes lacustris community was sampled at four different depths : $0,5 \mathrm{~m}, 1 \mathrm{~m}, 1,5 \mathrm{~m}$ and $2 \mathrm{~m}$. Three samples, each of $400 \mathrm{~cm}^{2}$, were collected at each depth. Three samples, each of $400 \mathrm{~cm}^{2}$, were also taken in the Sparganium angustifolium community at 1 meter depth. Finally, the Nitella gracilis community was sampled using five cores of $12 \mathrm{~cm}$ diameter, at $4 \mathrm{~m}$ depth.

\section{Results}

The bathymetry of Lake Baciver is shown in Figure 1. It corresponds to a high water level situation (early summer). Water level fluctuations have been detected both in summer $(20$ to $30 \mathrm{~cm}$ ) and in winter (to $100 \mathrm{~cm}$ ). A central basin, with a maximum depth of 7,5 $\mathrm{m}$ and two shallow areas in the western and eastern parts of the lake can be observed. Main water inputs are located in the eastern part as well as in two places along the northern shore of the lake. There is also a small submerged spring on the south side of the lake. A narrow channel of nearly two meters depth longitudinally runs through the eastern part of the lake and canalizes water to the central part. There is only one outlet, situated in the western part, which partially flows underneath the moraine which plugs the lake. The lake bottom is basically sedimentary, but a small part of the shore is rocky. 


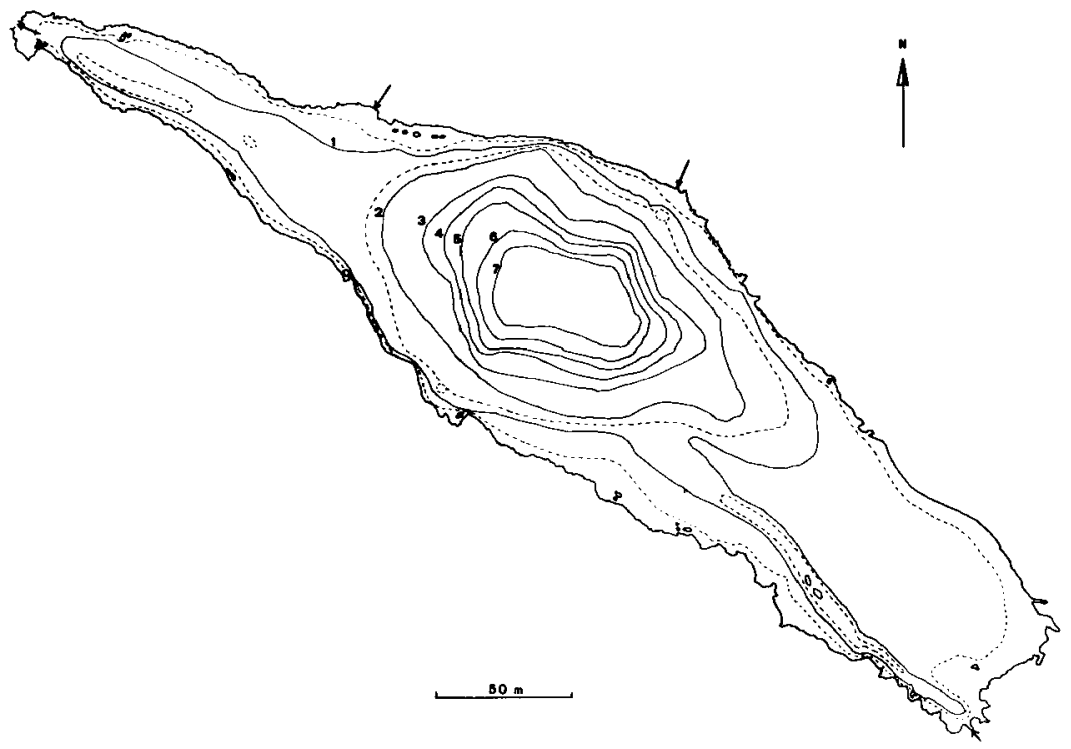

Fig. 1. Bathymetric map of Lake Baciver. Arrows indicate water inputs and water outputs

Morphometric features are summarized in Table II. The shallow mean depth of the lake must be emphasized (see Fig. 2).

Six species of benthic macrophytes have been collected with Isoetes lacustris $\mathrm{L}$. being the most abundant evergreen species. Isoetes setacea Lam. (I. brochonit Motelay) is very common within populations of Sparganium angustifolium Michx. in areas over $0,7 \mathrm{~m}$ in depth. Sparganium angustifolitm, Subularia aquatica $\mathrm{L}$. and lsoetes setacea, have an annual development and are always located in shallow areas over $1,5 \mathrm{~m}$ in depth. Specimens of a small evergreen species with morphological features in agreement with Eleocharis acicularis (L.) Roemer \& Schultes have been attributed to that species. Eleocharis acicularis usually appears mixed with Sparganitum angustifolium and Subularia aquatica or in patches

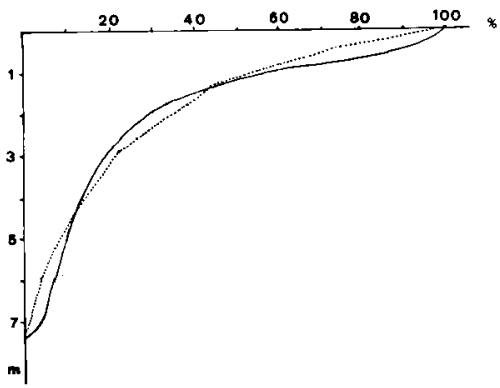

Fig. 2. Percentage area/depth curve (solid line) and percentage volume/depth curve (dotted line) in Lake Baciver. 
Table II. Morphometric parameters from Lake Baciver : Area, maximum length (Lmax), maximum width (Bmax). shore perimeter (1), volume (V), maximum depth (Zmax), mean slope (Im), basin area (Ac), mean width (Bm), mean depth $(\mathrm{Zm})$, relative depth $(\mathrm{Zr})$, shore development (DL) and some important quotients

\begin{tabular}{lr}
\hline Area $\left(\mathbf{m}^{2}\right)$ & 26629 \\
Lmax (m) & 432 \\
Bmax (m) & 115 \\
$1(\mathrm{~m})$ & 1064 \\
$\mathrm{~V}\left(\mathrm{~m}^{3}\right)$ & 51140 \\
$\mathrm{Zmax}(\mathrm{m})$ & 7,5 \\
$\mathrm{Im}(\%)$ & 10,2 \\
Ac $\left(\mathrm{hm}^{2}\right)$ & 588 \\
$\mathrm{Bm}(\mathrm{m})$ & 62 \\
$\mathrm{Zm}(\mathrm{m})$ & 1,9 \\
$\mathrm{Zr}(\%)$ & 4 \\
$\mathrm{DL}$ & 1,8 \\
$\mathrm{Zm} / \mathrm{Zmax}$ & 0,25 \\
Ac/A & 221 \\
Ac/ $\left./ \mathrm{m}^{-1}\right)$ & 115 \\
\hline
\end{tabular}

of variable size between Isoetes lacustris populations. Finally, Nitella gracilis (Smith) Agardh constituted a monospecific population in the central, deepest part of the lake, between September 1987 and September 1988 but it did not exist before and after these dates.

The emerged shores have a vegetation typical of cold and damp places, with peat -moss bogs dominated by Sphagnum (S. subnitens Russ. \& Warnst., and others) and boreo-alpine peat fens with Carex echinata Murray, C. nigra (L.) Reichard, Juncus filiformis L., Eriophorum angustifolium Honckeny, Viola palustris $\mathbf{L}$. and Pamassia palustris L. (Caricetum nigrae Braun Blanquet, 1915). There are no helophytic belts around the lake.

Three main vegetation units can be discerned related to the dominance of Sparganium angustifolium, Isoetes lacustris or Nitella gracilis (Table III).

The Sparganium angustifolium community mainly appears in shallow waters where a relatively high hydrodynamism exists because of water flow. This community is fully developed in the river mouths. It is composed of a high stratum of Sparganium leaves and a low, basal stratum of Subularia aquatica, Isoetes setacea and Eleocharis acicularis. In some cases, such as in channel margins, Sparganium angustifolium may be the only species. Juveniles of Isoetes lacustris can also be detected in this community. The main species, S. angustifolium, is a geophyte ; its leaves appear in early July, one month after the thaw, reach their maximum biomass in late August, fruit in September and die in late October. Subularia aquatica presents an annual cycle germinating in early summer, flowering in August and producing seeds in September and survives for a long time under the ice. Leaves of Isoetes setacea do not appear until July and, in the case of Subularia leaves, they also subsist for a long time when the lake freezes. Eleocharis acicularis is evergreen and no changes in biomass have been detected through the year. In August, the whole commu-

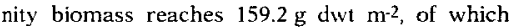
seventy per cent corresponds to Sparganium (Table IV).

The Isoetes lacustris community covers sedimentary bottoms of a great part of the lake over $2,3 \mathrm{~m}$ depth. Isoetes usually makes up monospecific stands but it can be mixed with Eleocharis acicularis, Subularia aquatica, Isoetes setacea and Sparganitum angusiffolium in areas over $1 \mathrm{~m}$ in depth. The appearance of the community remains almost constant through the year except for changes in accompanying species. There is a biomass increase with depth (Table $V$ ). There are no differences between 0,5 and $1 \mathrm{~m}$ in depth, nor between 1.5 and $2.0 \mathrm{~m}$ in depth (ANOVA, $p>0.05$ ) but there is a very significant increase between 1 and $1.5 \mathrm{~m}(\mathrm{p}<0.001)$. The lower boundary of the Isoetes beds is always sharp and it is usually found between 2.1 and $2.3 \mathrm{~m}$ in depth. Mean biomass values range between $120 \mathrm{~g}$ dwt $\mathrm{m}^{-2}$ and $460 \mathrm{~g} \mathrm{dwt} \mathrm{m}^{-2}$.

The Nitella gracilis community occupies sedimentary bot toms with low hydrodynamism and without Isoetes. Nitella developed in late summer 1987 . remainded fertile during the winter and spring under the ice and disappeared in late summer 1988. Nitella biomass was estimated to be $11.25 \mathrm{~g} \mathrm{dwt} \mathrm{\textrm {m } ^ { - 2 }}$ in June 1988.

Vegetation distribution in the lake is shown in Figure 3. Fifty per cent of the lake was covered by the Isoetes lacustris community with a total biomass of $3.5 \mathrm{Tm}$ dwt. The Nitella gracilis community covered thirty per cent of the lake bottom, while the Spargaritum community occupied only six per cent of the area. The other fourteen per cent of the lake did not support any macrophytic vegetation (Table VI). The minimum macrophyte biomass of the lake 
Table III. Species composition for the different communities.

V : dominant ; IV : very abundant ; III : abundant ; II : common ; I : rare ; $\mathbf{r}$ : accidental.

\begin{tabular}{|c|c|c|c|c|}
\hline \multirow[b]{2}{*}{ Species } & \multicolumn{4}{|c|}{ Isoetes - community } \\
\hline & $\begin{array}{l}\text { Sparganizm } \\
\text { community }\end{array}$ & $\begin{array}{c}\text { with } \\
\text { Sparganium }\end{array}$ & $\begin{array}{c}\text { without } \\
\text { Sparganium }\end{array}$ & $\begin{array}{c}\text { Nitella } \\
\text { community }\end{array}$ \\
\hline Sparganitum angustifolium Michx. & V & II & . & . \\
\hline Eleocharis acicularis (L.) Roe. \& Sch. & II & II & . & . \\
\hline Subularia aquatica $\mathrm{L}$ & II & I & . & . \\
\hline Isoetes setacea Lam. & II & I & & . \\
\hline Isoetes lacustris $\mathrm{L}$. & I & $\mathbf{I V}$ & $\mathbf{v}$ & $\mathbf{r}$ \\
\hline Nitella gracilis (Smith) Agardh & & & & IV \\
\hline
\end{tabular}

Table IV. Mean biomas of the different species in the Sparganium angustifolium community.

\begin{tabular}{lc}
\hline \multicolumn{1}{c}{ Species } & $\begin{array}{c}\text { Mean Biomass } \\
\text { gdwt/m }\end{array}$ \\
\hline Sparganium angustifolium & 109,6 \\
Eleocharis acicularis & 33,8 \\
Subularia aquatica & 15,8 \\
\hline
\end{tabular}

Table V. Mean biomass and standard deviation for the Isoetes lacustris community at four different depths. Results of the ANOVA are also indicated. Biomass is expressed in gdwt $\mathrm{m}^{2}$.

\begin{tabular}{cccccc}
\hline Depth $(\mathrm{m})$ & & 0.5 & 1.0 & 1.5 & 2.0 \\
\hline \multirow{2}{*}{0.5} & $\mathrm{~m}$ & 4.82 & & & \\
& $\mathrm{sd}$ & 2.63 & & & \\
& $\mathrm{~m}$ & & 5.55 & & \\
1.0 & $\mathrm{md}$ & & 3.42 & & \\
& $\mathrm{sd}$ & & & 13.64 & \\
& $\mathrm{~m}$ & & & 2.054 & $>0.05$ \\
1.5 & $\mathrm{sd}$ & & & 2.001 & $<0.001$ \\
& $\mathrm{~m}$ & & & & 17.56 \\
2.0 & $\mathrm{sd}$ & & & & 5.01 \\
\hline
\end{tabular}

Table VI. Lake area percentage covered by each community and estimates of macrophyte biomass of each community for the whole surface of the lake.

\begin{tabular}{lrc} 
& & $\begin{array}{r}\text { Biomass } \\
\text { Community }\end{array}$ \\
\hline Sparganium angustifolium & Area (kg dwt) \\
Isoetes lacustris & 5,6 & 239,3 \\
Nitella gracilis & 50,4 & 3462,2 \\
Sediment without macrophyte coverage & 29,7 & 89,0 \\
Rocky benthos & 2,1 & - \\
\hline
\end{tabular}

has been estimated to amount to $3.6 \mathrm{Tm} \mathrm{dwt}$, which is equivalent to $1400 \mathrm{~kg}$ of carbon. The maximum biomass should amount to nearly $4 \mathrm{Tm}$ dwt. Mean phytomass amounts to $135-150 \mathrm{~g} \mathrm{dwt} \mathrm{m}^{-2}$ (19-21 g C $\mathrm{m}^{-2}$ ).

\section{Discussion}

Shape and morphometry of Lake Baciver are typical of lakes of glacial origin. It is a small lake if compared with the main lakes from the Pyrenees (Margalef et al. 1975) but its dimensions agree with the means obtained in a local study from the lakes of Andorra (Central Pyrenees) (Campàs 1979). Its small water volume related to its large drainage basin sug. gests an important sedimentary input but, nevertheless, this input is minimized by other lakes at higher altitudes in the same drainage basin. The lake acts as a sediment trap with the sediment accumulation in the central part of the lake because it cannot accumulate on the slopes. Wind can be an important factor in removing sediment, mainly in the eastern part of the lake where shallow areas are very extensive Nevertheless, macrophyte coverage may decrease this phenomenon (Bulthuis et al. 1984).

The turnover rate can be estimated to be three days when the drainage basin area and average rainfall are taken into account (Catalan 1987). This value must be very variable through the year because water replenishment is nearly non existant in winter but it is very high at the time of the thaw and rainy periods. The thaw must also play an important role in redistributing the sediments, especially considering the shallow depth of the lake, because of the great amount of water that flows through the lake. The maintenance of the channel in the eastern part of the lake can only be explained as a result of floods. 


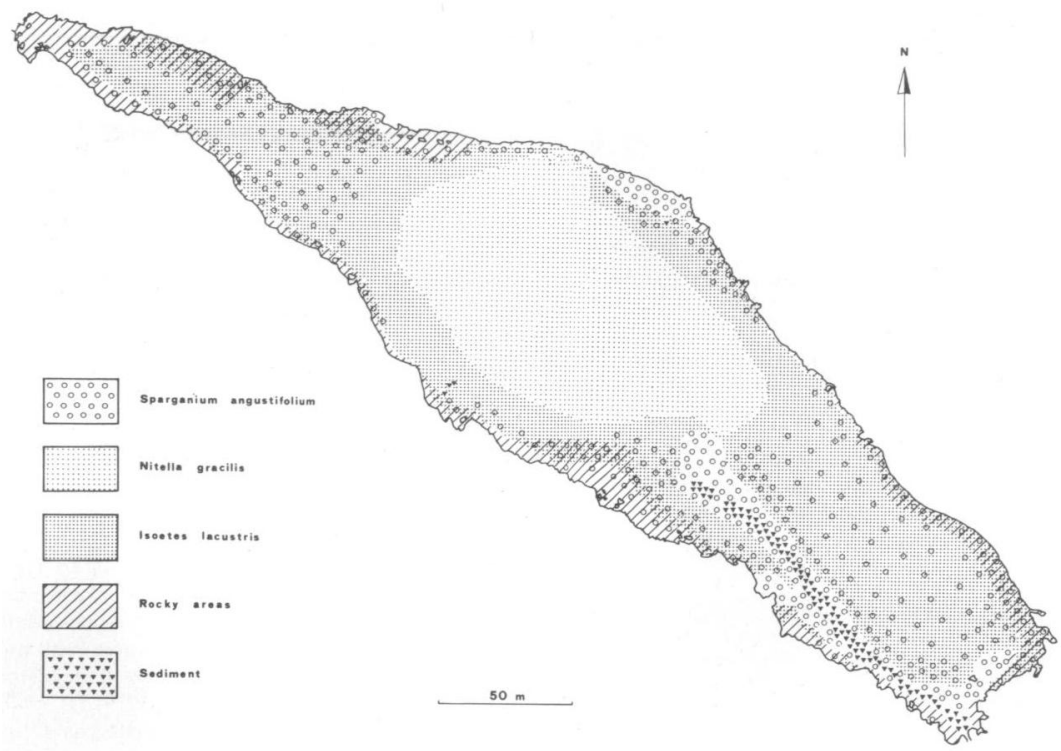

Fig. 3. Vegetation map of Lake Baciver.

The vegetation of the lake is dominated by isoe. tid species typical of oligotrophic and softwater lakes from central and northern Europe: Isoetes lacustris, Isoetes setacea, Eleocharis acicularis and Subularia aquatica (Spence 1964, Seddon 1972). Sparganium angustifolium is a very common natopotamid in boreal and mountain lakes (Cook 1980). Finally, Nitella gracilis is cosmopolitan and usually grows in water rich in humic substances (Corillion 1957).

The association of submerged vascular plants (Isoeto-Sparganietum angustifolii, Braun-Blanquet 1948) has only been described from eastern and central pyrenean lakes (Chouard \& Sauvage 1933, Claustres 1966, Carrillo 1984). Nevertheless, spatial segregation between Isoetes lacustris and Spargarium angustijolium populations has been recorded in some pyrenean lakes (Ballesteros \& Gacia 1988).
Isoetids are weak competitors (Hutchinson 1975) and they develop in places which are unfavourable for other vital forms of macrophytes. Carbon dioxide and nutrient availability seem to be factors limiting macrophyte grow th in oligotrophic waters with very low alkalinities (Adams et al. 1978, Sand Jensen \& Sondergaard 1978). Carbon dioxide uptake through the roots (Richardson et al. 1984), CAM metabolism (Boston 1986, Boston \& Adams 1986), low dark respiration (Sand Jensen 1978) and high roots/stem proportion (Kansanen \& Niemi 1974) are some of the strategies that permit the growth of isoetids in extremely poor waters. Sparganium angustifolium needs special conditions to outcompete Isoetes in these lakes. It usually appears in shallow places with relatively high hydrodynamism, where water movement destroys gradients, so nutrient availability increases (Ballesteros 1987) and air exposure of leaves allows Sparganium to take carbon 
dioxide from the air. A dense coverage of Sparganium tends to remove Isoetes mainly because of light and nutrient competition. So, Sparganium and Isoetes spatial niches do not coincide and segregation occurs. Nevertheless, there are no boundaries between Sparganium and Isoetes dominated communi. ties and all intermediates can be found in Lake Baciver and other lakes.

Isoetes substitution for Nitella in deep waters is common in oligotrophic, softwater lakes and it seems to be related to changes in the sediment (Macan 1970 ; Stross et al. 1988). The Nitella gracilis population from lake Baciver is atypical in the context of submerged vegetation in pyrenean lakes in that the Nitella neadows of the other lakes are usually constituted by species of the Nitella opaca complex (Ballesteros \& Gacia 1988). In the lake of Port Bielh (French Cent ral Pyrenees) the species has been classified as Nitella tlexilis Agardh (Capblancq 1973). Samples from a large number of lakes from the eastern and central Spanish Pyrenees have been classified as Nitella syncarpa (Thuill.) Chev. (Margalef Mir 1981).

Mean macrophyte biomass from Lake Baciver is very high in comparison with boreal lakes (Nygaard 1958, Kansanen \& Niemi 1974, Moeller 1975. Sand Jensen \& Sondergaard 1979). Small size, high turnover rate and shallow depth may increase production as a result of a higher hydrodynamism (Margalef 1985). Other explanations for this high biomass could be sediment features (Barko \& Smart 1986), yearly irradiance distribution or any other factor reducing plant stress.

Depth biomass distribution of Isoetes lacustris is atypical, with increasing values with depth until a sharp lower boundary. A progressive decrease in water level has been detected all through the winter due to the reduced water input, the continuous water loss and the pressure exerted by the ice and snow cover. Isoetes leaves from populations above $1 \mathrm{~m}$ in depth have been found to be flattened and partially inclosed in black ice during April 1988. So, ice-scour stress could explain differences between shallow and deep water Isoetes meadows as it occurs in boreal regulated lakes (Rorslett 1984). The lower boundary of the Isoetes population cannot be explained by light limitation because irradiance reaching the Isoetes lower boundary is about $50 \%$ (authors unpublished data). Also, there are no appreciable slope changes between 2 and $2.5 \mathrm{~m}$ depth that could explain its sudden disappearance. Changes in sediment features (Anderson \& Kalff 1988), mainly water content, could be responsible for this. Compactness of sediment diminishes with depth, so spores remain deeper in the sediment. There, spore germination and growth of the young plants can be prevented because of light limitation, as it has been reported for Lobelia dortmanna (Farmer \& Spence 1987). Isoetes growth can also be decreased by reduced water movement and an increase in sedimentation rates.

Presence of sharp lower boundaries is usual in submerged macrophyte populations (Spence 1964. Moeller 1976, Rorslett 1985, Szmeja 1987). The reason has been attributed to a combination of two synergistic effects that determine the disappearance of a species at a definite point along the vertical gradient (Watkinson 1985). Effects may differ in every case, so future research on the factors that take part in Isoetes distribution in Lake Baciver may answer this question.

\section{Acknowledgements}

Comments and criticisms from $D^{\text {rs }} \mathrm{J}$. Catalan and D. Serrat are much apprexiated. $X$. Baulies provided technical assistance in communities surface calculations. G. Carreras drew figures 1 and 3 . Financial support was provided by a grant from the Caixa de Barcelona.

\section{References}

Adams (M.S.), Guilizzoni (P.) \& Adams (S.). 1978. - Relationship of dissolved inorganic carbon to macrophyte photosynthesis in some Italian lakes. Limnol. Oceanogr., 23 : 912-919.

Anderson (M.R.) \& Kalff (J.). 1988. - Submerged aquatic macrophy te biomass in relation to sediment characteristics in ten temperate lakes. Freshwater Biology, 18:115-121.

Batlesteros (E.). 1987. - Production of seaweeds in Northwestern Mediterranean marine communities : its relation with environmental factors. In J. Ros (ed.) : Proceed. 22 nd EMBS. Barcelona.

Ballesteros (E.). 1988. - Contribució al coneixement floristic de l'Alta Ribagorça i la Val d'Aran. Butll. Inst, Cat. Hist. Nat., 57 : $75-83$.

Ballesteros (E.) \& Gacia (E.). 1988. - Els macrófits aquàtics dels estanys del Parc Nacional d'Aigites Tortes i Estany de Sant Maurici. Actes Primeres Jomades Recerca Parc Nacional d'Aigües Tortes i Estany de Sant Maurici.

Barko (J.W.) \& Smart (R.M.). 1986. - Sediment-related mechanisms of growt h limitation in submersed macrophytes. Ecology, 67 (5): $1328-1340$.

Boston (H.L.). 1986. - A discussion of the adaptations for carbon acquisition in relation to the growth strategy of aquatic isoetids. Aqtiat. Bot, $26: 259-270$.

Boston (H.L.) \& Adams (M.S.). 1986. - The contribution of crassulacean acid metabolism to the annual productivity of two aquatic vascular plants. Oecologia, 68:615-622.

Boudouresque (C.F.). 1971. - Méthodes d'étude qualitative et quantitative du benthos (en particulier du phytobenthos). Tethys, 3 (1) : $79-104$. 
Braun Blanquel (J.). 1948. - La végétation alpine des Pyrénées Orientales Comm. SIGMA, $98: 1-306$.

Bulthuis (D.A.), Brand (G.W.) \& Mobley (M.C.). 1984. - Suspended sediments and nut rients in waters ebbing from seagrasscovered and denuded tidal mudflats in a southern Aust ralian embayment. Aqtiat. Bot., $20: 257-266$.

Campàs (L.). 1979. - Els llacs i els estanys. In R. Folch (ed) : El Patrinomi Natural d'Andorra : 223-251. Ketres. Barcelona.

Capblancq (J.). 1973. - Phytobenthos et productivité primaire dun lac de haute montagne dans les Pyrenées Centrales. Annls. Limnol. 9 (3) : 193-230.

Capblancq (J.) \& Laville (H.). 1963. - Le lac de Port Bielh (Pyrénées) : exemple de fonctionnement d'un ecosystème lacustre de haute montagne. In M. Lamot te \& F. Bourlière : Problèmes d'Ecologie: Structure et fonctionnement des écosystèmes limniques : 51-80: Masson, Paris.

Carrillo (A.). 1984. - Flora i vegetació de t'alta mumanya de les valls d'Espot $i$ Bot. Tesi Doctoral. Universitat de Barcelona.

Catalan (J.). 1987. - Limnologia de l'Estany Redo (Pirineu Centrai). El sistema pelàgic d'un llac profund d'alta muntanya. Tesi Doctoral. Universitat de Barcelona. 230 pp.

Claustres (G.). 1966. - Les glumales des Pyrénées ariégeoises centrales : recherches d'écologie descriptive et d'écologie causale. Botanica Rhedonica, A (1): 1-493.

Cook (C.D.K.). 1980. - Sparganium L. In T. G. Tutin et al. (eds.) : Flora Europaea, vol. V: 274-275, Cambridge University.

Corillion (R.). 1957. - Les Charophycées de France et d'Europe Occidertale. Bull. Soc. Sci. Bretagne, 32.

Cosie (H.) \& Soulié (J.A.). 1913. - Florule du Val d'Aran. Le Mans.

Cheuard (P.) \& Sauvage (C.). 1933. - Nouvelles observations sur Jes éléments floristiques du Massif de Néouvielle et de la Vallée d'Aure. Bull. Soc. Bot. Fr., 80: 237-240.

Farmer (A.W). \& Spence (D.H.N.). 1987. - Flowering, germination and zonation of the submerged aquatic plant Lobelia dort. manna L. J. Ecol., 75 : 1065-1076

Hutchinson (E.G.). 1975. - A treatise on Limnology. Vol. III. Limnological Botany. John Wiley \& Sons. New York. 660 p.

Kansaren (A.) \& Niemi (R.). 1974. - On the production ecology of isoetids, especially Isoetis lacustris and Lobelia dortmanna, in Lake Päajärvi, southern Finland. Ann Bot. Fennici, 11 : $178-187$.

Macan (T.T.). 1970. - Biological studies of the English Lakes. Longman. London. $260 \mathrm{pp}$.

Margalef (R.). 1985. - From hydrodynamic processes to structure (information) and from information to process. Can. J. Fish. Aquat. Sci., $213: 200-220$.

Margalef (R.), Campàs (L.), Miracle (M.R.) \& Villaseca (J.M.). 1975. - Introducción al estudio de los lagos pirenaicos. Naturalia Hispanica, $4: 147$.
Margalef Mir ( R.). 1981. - Distribución de los macrófitos de las aguas dulces y salobres del E y NE de Espana y dependencia de la composición quimica del medio. Fund. 1. March. Ser. Univ., 157: 1-62.

Moeller (R.). 1975. - Hydrophyte biomass and community structure in a small, oligotrophic New Hampshire lake. Verh. Intem Verein. Limnol, 19 : 10041012.

Moeller (R.). 1978. - Seasonal change in biomas.s tissue chemistry, and net production of the evergreen hydrophyte Lobelia dortntama. Can. J. Bot., 56 : 1425-1433.

Nygaard (G.) 1958. - On the productivity of the bottom vegetation in Lake Grane Langso. Verh. Interm. Vevein. Limnol., 12 : 144-155.

Richardson (K.), Griffiths (H.), Reed (M.L.), Raven (J.A.) \& Griffiths (N.M.). 1984. - Inorganic carbon assimilation of the isoetids Isoetes lacustris L and Lobelia dortmanna L. Oecologia : 61 : 115-121.

Rorslett (B.). 1984. - Environmental factors and aquatic macrophyte response in regulated lakes. A statistical approach. Aquat. Bot., $19: 199-220$.

Rorslett (B.). 1985. - Death of submerged macrophytes. Actual field observations and some implications. Aquat. Bot., $22: 7-19$.

Sand-Jensen (K.). 1978. - Metabolic adaptation and vertical zonation of Littorella uniflora (L.) Aschers, and Isoetes lacustris $\mathrm{L}$. Aqual. Bot., $4: 1-10$.

Sand Jensen (K.) \& Sondergaard (M.), 1978. - Growth and production of isoetids in oligotrophic lake Kalgaard, Denmark. Verh. Inlent. Verein. Limnol., 20 ; 659-666.

Sand.Jensen (K.) \& Sondergaard (M.). 1979. - Distribution and quantitative development of aquatic macrophytes in relation to sediment characteristics in oligotrophic lake Kalgaard, Denmark. Freshwater Biology, 9:1-11.

Sedidon (B.). 1972. - Aquatic macrophytes as limnological indicators. Freshwater Biology, $2: 107-130$.

Spence (D.H.N.). 1964. - The macrophytic vegetation of freshwater lochs, swamps and associated fens. In J. H. Burnett (ed.): The vegetation of Scotland: 306-345. Oliver \& Boyd. Edinburgh,

Stross (R.G.), Huvane (J.) \& Sokol (R.C.). 1988. - Internal structure of deep-dwelling Nitella meadows. Aquat. Bot., $29: 329-345$.

Szmeja (J.). 1987. - The structure of a population of Lobelia dortmanna $\mathrm{L}$ along a gradient of increasing depth in an oligotrophic lake. Aquat. Bot., $28: 1-13$

Watkinson (A.R.) 1985. - On the abundance of plants along an environmental gradient. $J$. Ecol., 73 : 569-578. 